Journal of Social Sciences 1 (3): 136-140, 2005

ISSN 1549-3652

(C) 2005 Science Publications

\title{
The Process of Getting Identity in Turkish Society: Kemalist Education
}

\author{
Nihat Aycan \\ Celal Bayar University, Applied Sciencies Institute, 45040, Manisa,Turkey
}

\begin{abstract}
Education has different meanings according to the structure of the society and it works as to the structure. In one hand, it prepares the members of a society to the world standards changing rapidly and on the other hand, by designating the future form of the societies, increases its significance day by day. As Atatürk indicates education has an important role in the identity change of Turkish Society. Most probably Kemalist Education, as it is today, is going to be informative for Turkish Society in the future. In the research, in the light of these social realities, the social conditions providing the foundation of Republic, the period from those times to present, education that originates from Atatürk's perspective of and evaluating the spreading of the perspective in the centre of education are examined.
\end{abstract}

Key words: Turkey, education, ottoman state, Kemalist education

\section{INTRODUCTION}

Atatürk is not only a warrior for Turkey, but also the pioneer who indicates the modern solutions in each field for Turkish Nation. His principles have turned into an institution. Because of this, education, which is the most important vision of him, as he mentioned, must be introduced universally ${ }^{[1]}$.

In every society, education is the basic institution because of the its various and important functions; in regard of the level of complexity and change speed of the social construction, it occurs and works in different ways.

In order to explain the adventure of Kemalist education, we only evaluate the acquiring of intentional getting culture period and transfer of culture ${ }^{[2]}$. Because, if these dimensions of education are ignored, in one hand the continuity of a nation-state becomes risky, on the other hand the existence of a society, which is beneath the necessities of the age, will be in danger. Atatürk who knows this social reality, by saying "education is the thing that makes the nation free, independent, glorious, lofty or makes it dependent and poor", states that the first thing to be done must be organizing the education system. Atatürk, getting the education to the centre of reforms, indicates the importance of the negative affects of traditional education system in our society and says that traditional education system is the most important problem of our society ${ }^{[1,3]}$. Because of this, in order to make clear the process of getting our identity with Kemalist Education, we need to know education deeply, which has an important place among Atatürk's Reforms. And in order to achieve, this we need to learn the recent traditional Turkish Education briefly.

\section{MATERIALS AND METHODS}

We are going to evaluate Atatürk's opinions about education by focusing on the questions, "what did he do?", "why did he do?", "how did he do?" and we are going to explain the contributions of them to Turkey. First of all, we are going to evaluate briefly the conditions that prepare the Turkish Republic and how the education system before Republic is constructed, exists and works. In order to be subjective in our evaluation, we are explaining the subject chronologically. For the subject, we do not need to be go back to the beginnings of Turkish History. Evaluating the most recent Turkish History, the education system of Ottoman State is adequate.

\section{INVENTIONS}

Education in Ottoman State, which provides the emerging of Kemalist education, was in medresseh where religion was the most important thing. In male children schools (primary schools), the first level of medressehes, though the necessary information for daily life was given, they were very superficial. Mostly the Holy Koran that based on religious foundations was thought and the main target was, preparing for the other world. According to this perspective, which was supported by the saying "To be consent to one cardigan and one morsel", individual refusing daily pleasures, thought to be well educated ${ }^{[1,4]}$. Traditional Ottoman education, except "Palace School" bringing up the civil servants and staff just for governmental works and "Inexperienced Male Children School" preparing students just for this school and for army, based on rote learning. This type of education obstructs the growing 
up of the creative generations ${ }^{[1,4]}$. However, in the same period, the minorities in Ottoman State were educated in private schools. Their education was based on their own social realities and on transferring their own tradition. Briefly, the education in Ottoman State was very different in three various ways.

Atatürk says, "If nations want to be developed, they need to abandon their own traditions". He has also stated the characteristics of the education system in Ottoman State briefly ${ }^{[3]}$. In respect of this;

* The education system of Ottoman State is based on traditional methods and values. This type of education system cannot get along with the standards and social needs of the world changing rapidly. So, ignorance and illiterateness has increased in the society.

* The education system of Ottoman State is based on superficial information instead of the true dynamics of social life. The existence of a society is impossible whose members do not know social life but have superficial information.

* The education system of Ottoman State is based on rote learning. By this way the creativity of the individuals is reduced. So this type of education system is unnecessary.

* In the last periods of Ottoman State, the politics of education have changed rapidly. Besides, each Minister of Education has different programs. This situation is very inconvenient.

* Most importantly, the education system in Ottoman State was not national. It was not suitable both with its content and base for the development of National Culture. However, after French Revolution, Third Republicanists and at the end of the XIX. Century the American Primary School teachers state that the main target of education was to teach national values; also England put a similar method into practice ${ }^{[5]}$.

The education of Ottoman State was in different places and was given by different teachers who had different ideologies and who brought up generations who became as enemies. The education system was sufficient in Ottoman State because they did not know the concept of Nation-State and everybody was tried be gathered under the Ottoman identity. Since 1700's it became inadequate because of the changing standards. New arrangements must have been done in the institutions of education. But in the establishment period, Ottoman State explained that the main target of the state was strengthening the social construction, instead of "modifications in world politics". Because of this, the arrangements about education started from Military Schools ${ }^{[6]}$. With Administrative Reforms, Junior high school (secondary schools), Senior high schools (high schools) and The College of Literature, The College of Laws and other schools turned to be "modern education institutions in Western styles". However, all these institutions of education were not enough for the expectations of the society and could not solve the problems because they were established without sufficient background, without teachers with enough scholarly information and without education programs.

Ottoman State did not arrange its politics according to the conditions of the world that changes rapidly. It was important for the modifications of education institutions as the institutions of West. In this respect, on one hand Ottoman State had the same world politics against Europe, one the other hand wanted help from Europe in order to modernize the military. As a result of its wrong world politics, Ottoman State could not obstruct the loss of power in spite of its efforts. It was said to be "sick man" and was started to say that even its political independence was not in secure ${ }^{[6]}$. Briefly, we can say that, though some efforts were seen to modernize the education system, in the last periods of the Ottoman State, political construction and social construction which was arranged politically were disorder, tumult. And as a result of these the modernization movement in education system was very limited. The problem of different constructions in education system could never be solved. Turkish Society went through Republic Period with these problems. When we consider that more than $90 \%$ of the society was illiterate in that time, it becomes clear that one of the main problems of the Republic was education; moreover it was the basic problem ${ }^{[4,7]}$.

Atatük took over the educational problem of Turkey and other problems of the Ottoman State. His general ideas have been explained above. As he grew up in a military education institution in which the modernization movements were most common, he had the knowledge of the social forming preparing the collapse of the state. So Atatürk planed his reforms about education in the past and even he went on some of his studies during the Turkish War of Independence. In 16th July 1921, while gunfires were very close to Polatl1; he gathered the Congress of Education and discussed the basic education program. This attitude indicates his determination in this subject. And Atatürk, by the war of independence and education, explained the way of constructing modern Turkish Society and the characteristics of education that would be effective in the dynamic future of the society. In 1922, Atatürk said, " The true salvation of a nation is based on the success in education". The characteristics of Atatürk's politics about education in articles will help to make the subject concrete $^{[8]}$. In this respect, according to Atatürk;

* Education must be national, individuals must be educated to protect their own national values, government, the Turkish Chamber of Deputies and their society and basic principles which constitute Turkish Republic such as Republicanism, 
Populism, Nationalism, Revolutionism, State Socialism, Secularism must be given to Turkish society by all means ${ }^{[8,9]}$.

* Education must take "science" as its basis and must take form and work according to this. The aims, contents and means of education must be arranged in respect of recent scientific data so that Turkish art, economy, poetry and literature, in short Turkish nation can develop with all its beauties ${ }^{[1,8,9]}$.

* The institutions of education must be united; all of them must be gathered in the same field ${ }^{[8,9]}$. Thus, the unification of the institutions of education, which Ottoman could not realize at all, became real with the Unification of Instruction law that was put into effect in 1924, at the very beginning of Republican regime. Both Christian schools, which were established under the shadow of the capitulations and Muslim schools were abolished because of this idea and it was declared that the other institutions of society must compromise with culture $^{[3,10]}$

* Ignorance in all sections of society must be removed. Atatürk who knew that was only possible with education claimed, "if we want the real salvation first of all we must annihilate ignorance with all our might and speed" then added "the foundation of national education must obliterate ignorance, being unable to do this means we make no progress and all these are the signs of our society's retrogression". He indicated what he aimed in the light of education by stating "everyone's duty about this subject is never to think ignorantly, in realization of that there is not any hindrance in terms of reason, logic and religion and if there emerges any difficulty, to eliminate them is a duty, an obligation and a command of God for the people who think about the glory, honour and the future of their country" $\left.{ }^{,[}, 9\right]$. He revealed all these in practice either by establishing national schools in all sections of society, or by setting literacy courses in the army. The people, who were successful during military service, were commissioned to teach reading and writing to the individuals of their residence when they were discharged.

* Atatürk, claiming that in a country which Turkish was spoken Turkish must have been used in reading and writing, replaced the alphabet which was a great change that non of the reformists could venture in the past ${ }^{[1,10]}$. His response to the people who offered a five year transition period for the replacement of the alphabet was: "Either we apply it in three months, or we never do" ${ }^{,[1]}$. He himself travelled without making discrimination between country and town for that. He was in the vanguard of the Turkish society when he got in front of a blackboard as a headmaster to give lessons on the alphabet in different levels through the adaptation of the new alphabet. According to Atatürk, language is both the main element of being a nation and an important means of unification of education and culture. So, the Turkish nation will show that it is near the contemporary civilization with its writing and its reason. Consequently, teaching a language both to women and men is a patriotism and nationalism duty ${ }^{[1,10,11]}$.

* According to Atatürk, "Education must be equal, discrimination of sex must be removed, girls and boys must participate friendly in education with equal standards. At first students must be able to bring out their ideas freely in a democratic education environment, so the conditions of equality can be constituted. Also, it will not be sufficient for women to take place with men freely and equally. If the Turkish women want to be the real mothers of the nation they must be more intellectual and virtuous than men. Only with such a participation, reforms will be more successful $^{8,11,12 \uparrow}$.

* Success in education depends on the teachers. As to Atatürk's statement "What raises peoples to the level of a real nation are the teachers. New generation, which has an independent reason, knowledge and conscience will be the achievement of the teachers. The value of the achievement is measured with the skill and self-sacrifice of the teacher. The success of the teachers will be the

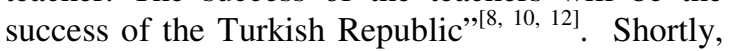
since teachers are always the people who plan, apply, follow and evaluate the education system, they will the only ones who will carry out an accomplished education system. So, the teachers are not only the experts of their branches, but also the guides who prepare individuals for their social roles. Briefly, Atatürk qualified the teachers as "the most self-sacrificing and respectful people all around the world." He said that teachers' duties, responsibilities and social status were particularly significant for him and he also protected them with his acts ${ }^{[8,13]}$.

* As to Atatürk, "As in all areas of social life, discipline and virtue are the main elements in education" ${ }^{[12]}$.

* Atatürk, who declared that "An applied education which depends on work and study must be taken basis, via work people must be educated; education must be valid in economic life and accomplishment must be fulfilled." equipped the school of agriculture in Ankara, which Stephen Ronerd praised in his book called Today's Turkey, with modern laboratories, conference and exhibition halls, sport centres, libraries, dormitory for the student and the teachers, residential and tennis courts. Atatürk stated that "Even the practical side of the work must be thought to individuals, so at 
the end of the education process they can take place in the institutions of economy immediately". $\mathrm{He}$ also pointed out "The requirements of the economic institutions must take place in education schedules" $" 10,14]$.

The aim of Kemalist education as a consequence of social, radical changes which were injected to society most rapidly in various ways as above-mentioned in articles causes Turkish society to gain a different identity with a different policy from the period before Turkish Republic. This kind of education means firstly "scientism" and then "open-mindedness", "inclination towards practice", "productiveness" and "an activity which must be carried out with a determined discipline". New ideas were injected to Turkish society with Kemalist Reform, which was consented by Turkish Parliament in 1920's.

\section{DISCUSSION AND CONCLUSION}

Atatürk, secular notion leader of Turkey in 1920 and 1930's not only pointed out his ideas about policy theoretically, but also pioneered their application to everyday life. In 1920, while the ministries were constituted in order to solve some fundamental problems, education affair was emphasized as an important problem, which must have been solved even if it was not mentioned in the level of any ministry. An accomplishment like Atatürk's was not seen in the world $^{[3,15,16]}$. Atatürk who made the university reform in 1933, while abolishing Istanbul University (Darülfünun), he tried to establish universities as science centres not only in specific places like Istanbul, Ankara, but also in Anatolia, for instance in $\mathrm{Van}^{[1,8]}$. Again, at about the same time, Atatürk provided scientists, who wanted to leave their country because of the uneasiness in Germany, with some resources; invited them to Turkey and enabled a lot of branches of science such as medicine, law, economy, philosophy and psychology to develop with the help of these scientists.

The peasantry characteristic of our society, which becomes meaningful in Atatürk's aphorism, "Peasants are the masters of a nation." marked the education in the period after Atatürk; the efforts of setting educational studies in the villages were carried on as Atatürk defined ${ }^{[8]}$. For that reason, "Village Institutes" which had teachers who were especially chosen from the same village with them or a near village were established. "Village Institutes" which were in practice most commonly in 1940's are the educational models peculiar to Turkey that were mentioned with praise and admiration by European countries ${ }^{[17,18]}$.

Educational improvements in Türkiye still go on. For example, basic education, which is 10-12 years in Europe and in developed countries, was raised to eight years in Turkey. The preparations to have 12-year basic education in Türkiye show the determination in reaching the level of the developed countries and modernity. This determination was revealed by the diffusion of universities in most of our countries and institutions of higher education attached to the universities in a lot of counties. However, as soon as the quantitative increase is not supported with the qualitative increase and autonomy cannot be provided from scientific, administrative and economic points of view, the expected benefit of education cannot be obtained. But, this kind of improvements, which have been made from the lowest to the highest level of institutions of education, can be evaluated as a sign of other improvements ${ }^{[19]}$. The attainment of $90 \%$ in our society's education level with a rapid increase, especially in basic education degree, is hopeful ${ }^{[6]}$. In general education, even if education level of the members of the Turkish society is not yet in the desired degree, especially the accomplishment of Turkish women's lessening the distinction between sexes in the field of learning reading and writing has been appreciated internationally with mentions, thanks and great prizes since 1980's.

Consequently, as it is seen in the model of Kemalist education, education is the most definite way that will provide the societies with modernity. Therefore, "Perfection is the enemy of success." principle must be accepted and the determination in being a Kemalist society must not be abandoned. Because, the principle of the education reform which constitutes the foundation of Turkish society, in fact are the principles of human rights in our time. Hence, the world must be aware of either new or old ideas, which can be injected to historical reality by the reformists like Atatürk.

\section{REFERENCES}

1. Atatürk, M.K., 1988. Türk Yazı İnkılabı, Milli Kültür (3), (In Turkish).

2. Ertürk, S., 1975. Eğitimde Program Geliştirme, Ankara, Yelken Tepe Publication (In Turkish).

3. Kucuradi, I., 1995. Secularisation in Turkey. Free Inquiry, 16: 1.

4. Koçer, H.A., 1992.Türkiye'de Modern Eğitimin Doğuşu ve Gelişimi, Istanbul, Ministry of Education, (In Turkish).

5. Bottomore, T.B., 1994. Toplumbilim, Istanbul, Der Publication (In Turkish).

6. Aycan, N., 1999. Osmanlıda İnsan Haklarının Sosyolojik Analizi, Osmanlıda İnsan Hakları Uluslararası Sempozyumu, Manisa-Turkey (In Turkish).

7. Aycan, N., 2004. Eğitim ve Kadın: Manisalı Kadinlar, First International Conference on Women's Studies, April 29-30, Famagusta-North Cyprus (In Turkish). 
8. Kocatürk, U., 1999. Atatürk'ün Fikir ve Düşünceleri, Ankara, Atatürk Kültür, Dil ve Tarih Yüksek Kurumu Atatürk Araştırma Merkezi (In Turkish).

9. Genel Kurmay Başkanliği, 1984. Atatürkçülük, Istanbul, Milli Eğitim Publication (In Turkish).

10. Benoist-Mèchin, J., 1997. Mustafa Kemal Bir İmparatorluğun Ölümü, Ankara; Bilgi Publication (In Turkish).

11. Aleksic, D., 1996. Le Caractère Laïque des Réformes d'Atatürk Dans le Société Turquie, The Second International Symposium on Atatürk, Septembre 9-11, Ankara, Turkey.

12. Aytaç, K., 1984. Atatürkçülük, Istanbul, Milli Eğitim Publication (In Turkish).

13. Çoban, A., 2001. Atatürkçü Düşüncede Eğitim Sistemi ve Boyutları, Milli Eğitim Dergisi (149) (In Turkish).
14. Oğuzkan, T.,1984.Atatürkçü Eğitim Politikası ve Milli Eğitim, Atatürkçülük, Istanbul; Milli Eğitim Publication (In Turkish).

15. Lewis, B., 1998. Modern Türkiye'nin Doğuşu, Ankara, Türk Tarih Kurumu Publication (In Turkish).

16. Sencer, M., 1986. Türkiye'nin Yönetim Yap1s1, Istanbul, Alan Publication (In Turkish).

17. Turkish National Commission For Unesco, 1981. Atatürk, Ankara, Türk Tarih Kurumu Puplication (In Turkish).

18. Dumoulin, D., 2004. Atatürk'ten Düşünceler. http://www.atam.gov.tr (Accession date: 05.05.2004).

19. Özdalga, E., 1999. Education in The Name of 'Order and Progress': Reflections on the Recent Eight Year Obligatory School Reform in Turkey, The Muslim World, (29). 